\title{
EFFECT OF BREWER'S DRIED GRAIN AND YEAST CULTURE ON GROWTH PERFORMANCE AND CARCASS TRAITS OF BROILER CHICKS
}

\author{
Mohamed A. Nour*, M.M. El-Hindawy, A.I. Attia and E.A. Ashour \\ Poult. Dept., Fac. Agric., Zagazig Univ., Egypt
}

\begin{abstract}
The present study was performed to investigate the effect of dietary brewers dried grain (BDG) and 2 levels of yeast culture (YC) (Saccharomyces cerevisiae) on growth performance carcass traits some dietary measurements and economical efficiency of broiler chicks during 1-6 weeks of age under Egyptian conditions (15 October - 30 November 2014) where the ambient temperature ranged between 20 to $26 \mathrm{C}^{\mathrm{o}}$. A factorial design $(5 \times 2)$ arrangement was performed included five levels of BDG $(0,3$, $6,9$ and $12 \%)$ and two levels of YC (0 and $0.5 \mathrm{~g} \mathrm{~kg}$ diet). The analysis of variance of the obtained results show a significant $(\mathrm{P} \leq 0.01)$ effect on live body weight $(\mathrm{LBW})$ at 6 weeks of age, body weight gain (BWG) through 3-6 weeks of age and during 1-6 weeks of age. There was a significant linear reduction in LBW and BWG as the BDG increased $(\mathrm{P} \leq 0.01)$. There is a significant difference $(\mathrm{P} \leq 0.05)$ between diet containing $12 \%$ BDG and other diets for LBW and body weight gain during the whole experimental period (1-6) weeks of age. This diet have the lowest LBW and BWG. It could be noticed that, LBW and BWG during all different experimental periods were not significantly affected by different levels of YC. Also, interactions between BDG and YC levels were not significant $(\mathrm{P} \leq 0.05)$ on LBW at 6 weeks of age and BWG through (1-6) weeks of age. Results obtained in this study showed that, levels of BDG did not affect $(\mathrm{P} \leq 0.05)$ average feed consumption through all different experimental periods whereas, the feed gain ratio (FCR) significantly increased $(\mathrm{P} \leq 0.05)$ by increasing levels of BDG to $12 \%$. The best value of FCR was 2.13 in the group of birds fed diet with $9 \%$ BDG. The present results did not show any significant effect on all carcass characteristics studied due to different dietary BDG and YC levels or their interactions, except giblets percentage, which was significantly $(\mathrm{P} \leq 0.01)$ affected by BDG levels and the interaction between BDG and YC levels. In conclusion, the results of this study indicated that, taking body weight gain, feed conversion and economical efficiency, the dietary level of $9 \%$ BDG with or without yeast culture supplementation may be the best percentage till 6 weeks of age. While yeast culture did not affect on the performance and carcass traits.
\end{abstract}

Key words: Brewers dried grain, yeast culuture, growrh performance, broilers.

\section{INTRODUCTION}

Feeding cost represents at least $65 \%$ of total cost for poultry production. Reducing feed cost is one of the important targets in poultry production. The increasing costs and limited quantities of animal protein available for use in poultry feeds has resulted in attempts to substitute plant proteins for part or all of the animal protein in a ration. Therefore, a considerable attention has been paid to use unconventional feedstuffs such as agro-industrial

\footnotetext{
*Corresponding author: Tel. : +201067933018

E-mail address: nmohmed732@gmail.com
}

by- products in formulanting poultry diets to achieve a suitable efficiency of utilization and economical efficiency of production.

By-products brewers dried grain is a byproduct of brewery industry, the residue is extracted from barley, wheat, maize, rice and oat. It contains the insoluble materials remaining after the process of soaking, mashing and boiling with water which includes crude fibre (CF) fractions, fats, proteins together with residues of starch and darine (Aregherore and 
Abdulrazak, 2005). The BDG or spent grain can be fed to livestock wet or dried but because the wet grains deteriorate easily, the product is usually dried (as a preservative measure) to obtain the brewers dried grain. Spent grain or BDG contains $93 \%$ dry matter (DM), $22.39 \%$ crude protein (CP), 19.1\% CF, 4\% ash, $48.6 \%$ non free extract (NFE), metabolisable energy (ME) $2360 \mathrm{kcal} / \mathrm{kg}, 6.2 \%$ ether extract (EE) (Longe and Adetola, 1983).

From the above, it is obvious that, BDG is high in $\mathrm{CP}$ and ME and hence could be used to reduce quantity of maize and soybean used in broiler ration. However, BDG usage is limited in monogastric animals because of its high fiber content, so it is not normally used in intensive feeding system. However some trails showed that BDG can be used for poultry feed (Parsons et al., 1983; Noll et al., 2001).

Chickens are monogastrics and do not possess the enzymes needed to digest high fiber diets. For this reason it has been difficult and uneconomical to substitute very cheap high fiber ingredients like rice bran, offal and BDG for the regular ingredients like maize which are relatively costly. In broiler rations, the use of appropriate feed additives offers an opportunity to overcome some of these potential limitations imposed by exclusively vegetable protein based diets which tend to contain more fiber than animal protein sources and poultry are known to be poor in digesting fibre (Longstaff and Nab, 1989). Yeast (Saccharomyces cerevisiae) has been traditionally used as growth promoters in poultry and other animals. Various researches on yeast have indicated that supplementation of yeast in diet is effective in improving growth and feed efficiency in broilers. Yeasts primarily targeted at grain or grain by-product compoments of the diets will have both direct and indirect benefits on the digestibility of vegetable proteins and fibrous matter in ration. Indirect benefits can arise when yeasts and metabolic enzymes breakdown the fibrous and nutrient components of the ration (Adejumo et al., 2005).

The aim of this study is to investigate the performance, carcass characteristics of broiler chicks fed varying dietary levels of BDG with or without yeast supplementation as an alternative feed thereby reducing the cost implication of animal feed to farmers.

\section{MATERIALS AND METHODS}

The present experiment was carried out at the experimental poultry farm, Poultry Department, Faculty of Agriculture, Zagazig University Egypt on (15 October - 30 November 2014).

This work was conducted to investigate the effect of dietary incorporation of different levels of brewers dried grains with or without supplementation of dry yeast culture on growth performance, carcass traits, of Cobb broiler chicks. A $5 \times 2$ factorial design experiment was conducted including five levels of brewers dried grains $(0,3,6,9$ and $12 \%$ in the diet) and two levels of yeast culture $(0.0$ or $0.5 \mathrm{~g} / \mathrm{kg}$ diet $)$ through the experimental period (1-6 weeks of age). A total number of 300 unsexed one week old Cobb broiler chicks were randomly distributed into 10 treatment groups of 30 chicks each with 3 replicates (10 chicks each). Chicks of all the experimental groups had nearly the same initial average live body weight and were not statistically different. Each experimental group of chickens was allotted on one of the experimental diets.

Birds were received starter diet till three weeks of age while finisher diet from the fourth to sixth weeks of age. Diets were formulated to cover the nutrient requirements during the starter and finisher periods according to NRC (1994), in which brewers dried grains was incorporated in the diet with or without dry yeast culture supplementation. Brewers dried grains and yeast culture were purchased from Multivita Company, $\mathrm{Six}^{\text {th }}$ of October, Egypt. Composition and calculated analysis of the experimental diets are shown in Table 1. Chicks were grown in brooders with raised floors and exposed to 24 hours of a constant light. Feed and water were supplied ad-libitum through the experimental period. Individual body weight of chicks was recorded at one, three and six weeks of age. Feed consumption data were weekly recorded on replicate basis to estimate feed conversion ( $\mathrm{g}$ feed $/ \mathrm{g}$ gain) during the experimental periods.

At the termination of the experiment, 30 broiler chicks (three from each group) were sampled randomly for carcass evaluations at 6 weeks of age, weighed and manually slaughtered. Economical efficiency (EE) of the product (growth rate) was calculated from the input 
Table 1. Composition and chemical analysis of the starter level diets through 1-3 weeks of age

\begin{tabular}{|c|c|c|c|c|c|}
\hline \multirow{2}{*}{$\frac{\text { Ingredient }}{\text { Yellow corn }}$} & \multicolumn{5}{|c|}{ Percentage } \\
\hline & 57.13 & 55.16 & 53.59 & 51.33 & 48.98 \\
\hline Soybean meal (44\%) & 31.65 & 30.60 & 28.80 & 28.17 & 27.65 \\
\hline Corn gluten meal $(60 \%)$ & 06.50 & 06.50 & 07.00 & 06.70 & 06.40 \\
\hline Brewers dried grain & 0.00 & 03.00 & 06.00 & 09.00 & 12.00 \\
\hline Di-Calcium phosphate & 01.70 & 01.70 & 01.70 & 01.70 & 01.70 \\
\hline Limestone & 01.24 & 01.22 & 01.22 & 01.22 & 01.20 \\
\hline Vit-Min Premix* & 00.30 & 00.30 & 00.30 & 00.30 & 00.30 \\
\hline $\mathrm{NaCl}$ & 00.30 & 00.30 & 00.30 & 00.30 & 00.30 \\
\hline DL Methionine & 00.05 & 00.04 & 00.03 & 00.02 & 00.02 \\
\hline L-Lysine & 00.13 & 00.14 & 00.16 & 00.16 & 00.15 \\
\hline Soybean oil & 1.00 & 01.04 & 00.90 & 01.10 & 01.30 \\
\hline Total & 100 & 100 & 100 & 100 & 100 \\
\hline \multicolumn{6}{|l|}{ Calculated analysis** } \\
\hline $\mathrm{CP}(\%)$ & 23.00 & 23.00 & 23.03 & 23.00 & 23.00 \\
\hline ME Kcal/kg diet & 2951 & 2950 & 2951 & 2951 & 2951 \\
\hline Ca (\%) & 01.00 & 01.00 & 01.00 & 01.00 & 01.00 \\
\hline P (Available\%) & 00.45 & 00.45 & 00.45 & 00.45 & 00.45 \\
\hline Lysine (\%) & 01.20 & 01.20 & 01.20 & 01.20 & 01.20 \\
\hline $\mathrm{M}+\mathrm{C}(\%)$ & 00.83 & 00.83 & 00.83 & 00.83 & 00.83 \\
\hline CF (\%) & 03.56 & 03.90 & 04.20 & 04.57 & 04.93 \\
\hline Price/ton (LE) ${ }^{* * *}$ & 3514.69 & 3436.43 & 3341.67 & 3274.84 & 3213.39 \\
\hline
\end{tabular}

"Growth vitamin and Mineral premix Each $2.5 \mathrm{~kg}$ consists of :

Vit A 12000, 000 IU; Vit D3, 2000, 000 IU; Vit. E. 10g; Vit k3 2 g; Vit B1, 1000 mg ; Vit B2, 49g; Vit B6, 105 g; Vit B12, $10 \mathrm{mg}$; Pantothenic acid, $10 \mathrm{~g}$; Niacin, $20 \mathrm{~g}$, Folic acid , $1000 \mathrm{mg}$; Biotin, $50 \mathrm{~g}$; Choline Chloride, $500 \mathrm{mg}$, Fe, $30 \mathrm{~g}$; Mn, 40 g; Cu, 3 g; Co, 200 mg; Si, $100 \mathrm{mg}$ and Zn , 45 g.

${ }^{* *}$ Calculated according to NRC (1994).

${ }^{* * *}$ Prices were calculated according the market price during (15 October - 30 November 2014). 
Table 2. Composition and chemical analysis of the level finisher diets through $<3-6$ weeks of age

\begin{tabular}{|c|c|c|c|c|c|}
\hline \multirow{2}{*}{$\frac{\text { Ingredient }}{\text { Yellow corn }}$} & \multicolumn{5}{|c|}{ Percentage } \\
\hline & 60.53 & 58.40 & 57.12 & 55.13 & 53.28 \\
\hline Soybean meal (44\%) & 27.15 & 26.27 & 24.13 & 23.06 & 21.75 \\
\hline Corn-gluten meal $(60 \%)$ & 06.10 & 06.00 & 06.65 & 06.65 & 06.80 \\
\hline Brewers dried grain & 00.00 & 03.00 & 06.00 & 09.00 & 12.00 \\
\hline Di-Calcium phosphate & 01.50 & 01.50 & 01.50 & 01.50 & 01.50 \\
\hline Limestone & 01.15 & 1.12 & 01.12 & 01.12 & 01.11 \\
\hline Vit-Min Premix* & 00.30 & 00.30 & 00.30 & 00.30 & 00.30 \\
\hline $\mathrm{NaCl}$ & 00.30 & 00.30 & 00.30 & 00.30 & 00.30 \\
\hline DL Methionine & 00.02 & 00.01 & 00.00 & 00.00 & 00.00 \\
\hline L-Lysine & 00.10 & 00.10 & 00.13 & 00.14 & 00.15 \\
\hline Soybean oil & 02.85 & 03.00 & 02.75 & 02.80 & 02.81 \\
\hline Total & 100 & 100 & 100 & 100 & 100 \\
\hline \multicolumn{6}{|l|}{ Calculated analysis** } \\
\hline $\mathrm{CP}(\%)$ & 21.00 & 21.00 & 21.01 & 21.00 & 21.00 \\
\hline ME Kcal/kg diet & 3099 & 3102 & 3101 & 3100 & 3101 \\
\hline $\mathrm{Ca}(\%)$ & 00.90 & 00.90 & 00.90 & 00.90 & 00.90 \\
\hline P (Available \%) & 00.40 & 00.40 & 00.40 & 00.40 & 00.40 \\
\hline Lysine (\%) & 01.05 & 01.05 & 01.05 & 01.05 & 01.05 \\
\hline $\mathrm{M}+\mathrm{C}(\%)$ & 00.74 & 00.74 & 00.74 & 00.75 & 00.76 \\
\hline CF (\%) & 03.31 & 03.66 & 03.95 & 04.29 & 04.62 \\
\hline Price / ton $(\mathbf{L E})^{* * *}$ & 3452.17 & 3381.85 & 3275.36 & 3200.69 & 3121.07 \\
\hline
\end{tabular}

"Growth vitamin and Mineral premix Each $2.5 \mathrm{~kg}$ consists of :

Vit A 12000, 000 IU; Vit D3, 2000, 000 IU; Vit. E. 10g; Vit k3 2 g; Vit B1, 1000 mg ; Vit B2, 49g; Vit B6, 105 g; Vit B12, 10 mg; Pantothenic acid, 10 g; Niacin, 20 g , Folic acid , $1000 \mathrm{mg}$; Biotin, 50 g; Choline Chloride, $500 \mathrm{mg}$, Fe, $30 \mathrm{~g}$; Mn, 40 g; Cu, 3 g; Co, 200 mg; Si, $100 \mathrm{mg}$ and Zn , 45 g.

** Calculated according to NRC (1994).

${ }^{* * *}$ Prices were calculated according the market price during (15 October - 30 November 2014). 
and output analysis based upon the differences in growth rate and feeding cost (Heady and Jensen, 1954) as follows:

$\mathrm{EE}=\frac{\text { Net revenue }}{\text { Price of feed to produce one kg live body weight }}$

Data were statistically analyzed on a $5 \times 2$ factorial design basis according to Snedecor and Cochran (1982) using SPSS ${ }^{\circledR}$ software statistical analysis program (SPSS, 1999), by adopting the following model:

$$
Y_{i j k}=\mu+B_{i}+Y_{j}+B Y_{i j}+e_{i j k}
$$

Where:

$\mathrm{Y}_{\mathrm{ijK}}=$ an observation,

$\mu=$ the overall mean,

$\mathrm{B}_{\mathrm{i}}=$ effect of brewers dried grains level,

$Y_{j}=$ effect of yeast culture level,

$\mathrm{BY}_{\mathrm{ij}}=$ effect of interaction between brewers dried grains and yeast culture levels,

$\mathrm{e}_{\mathrm{ijk}}=$ experimental random error.

Duncan's new multiple range test (Duncan, 1955) was used for comparison among significant means.

\section{RESULTS AND DISCUSSION}

\section{Growth Performance}

\section{Live Body Weight and Body Weight Gain}

\section{Brewers dried grain level effect}

Average live body weight (LBW) of broiler chicks as affected by brewer's dried grain (BDG), irrespective of yeast supplementation during the different ages are presented in Table 3 . The obtained results show that, within the first three weeks, there were no significant effects regarding (BDG) on LBW and BWG of broiler chicks. However, LBW at 6 weeks and BWG through <3-6 and 1-6 weeks of age were significantly $(\mathrm{P}<0.01)$ decreased in chicks fed diets containing BDG. It was noticed that, the reduction in LBW and BWG was increased with increasing BDG level in the diets from 3 up to $12 \%$.
No significant differences were detected between groups fed 3, 6 and 9\% dietary BDG. At 6 weeks of age LBW decreased by 8.65 , $11.88,8.9$ and $25.1 \%$ in chicks fed diets containing 3, 6, 9 and $12 \%$ BDG, respectively as compared with control. The corresponding values of BWG were 10.2, 11.5, 9.01 and $24.5 \%$, respectively.

It is well known that, the content of insoluble fiber and non-starch polysaccharides in the diets containing BDG is greater than that, in the control diet $(0.0 \%$ BDG). Moreover, Brewers spent grain (BSG) as a plant protein source contains more lignin and cellulose than soy, therefore, the total fiber content would have been even higher in the BSG diets (Denstadli et al., 2010).

Some studies showed that, as the inclusion of BSG increased the birds did not compensate for the reduced dietary metabolizable energy levels by increasing their feed consumption (Denstadli et al., 2010; Sabet et al., 2009). In these trials there was not significant different for feed intake between diets containing BSG. Although we fixed metabolizable energy level in the experimental diets with different concentrations of BSG, we observed this reduction in feed utilization too.

The present results agree with those obtained by Wondifraw and Berhan (2014) who showed that, growth rate was generally depressed progressively with increasing levels of Brewers dried grain yeast (BDGY) in white leghorn chicks ration and concluded that, BDGY could incorporated in chick's rations at the level of $18 \%$ without adverse effect on growth performance so as to increase the economical efficiency. Aghabeigi et al. (2013) concluded that BWG in broiler chicks fed diets containing BSG up to $20 \%$ through $11-42$ day and $5 \%$ through 25-42 day approached that of the control birds. Alabi et al. (2014), found that, increasing level of brewers dried grain and without commercial enzyme supplementation caused significant $(\mathrm{P}<0.05)$ decrease in weight gain.

\section{Effect of yeast supplementation}

The response of broiler chicks to varying diet of yeast supplementation irrespective of dietary BDG levels during the different ages are 
Table 3. Live body weight (LBW) and body weight gain (BWG) $(\bar{X} \pm$ SE) for broiler chickens as affected by brewers dried levels, yeast supplementation and their interaction

\begin{tabular}{|c|c|c|c|c|c|c|c|c|}
\hline \multirow[t]{2}{*}{ Item } & & \multicolumn{4}{|c|}{ Live body weight (g) (LBW) } & \multicolumn{3}{|c|}{ Body weight gain (g/day) (BWG) } \\
\hline & & Initial (1 wk) & 3 wks & $6 \mathrm{wks}$ & & $1-3$ wks & 3-6 wks & $1-6 \mathrm{wks}$ \\
\hline \multicolumn{9}{|c|}{ Brewers dried (BDG) effect } \\
\hline \multicolumn{2}{|l|}{$0 \%$} & $113.42 \pm 0.42$ & $580.58 \pm 18.49$ & $1884.67 \pm$ & $37.23^{\mathrm{a}}$ & $33.37 \pm 1.31$ & $62.10 \pm 1.60^{\mathrm{a}}$ & $47.74 \pm 1.00^{\mathrm{a}}$ \\
\hline \multicolumn{2}{|l|}{$3 \%$} & $114.67 \pm 0.46$ & $500.67 \pm 17.92$ & $1721.50 \pm$ & $43.08^{\mathrm{b}}$ & $27.57 \pm 1.30$ & $58.14 \pm 1.35^{\mathrm{ab}}$ & $42.85 \pm 1.23^{\mathrm{b}}$ \\
\hline \multicolumn{2}{|l|}{$6 \%$} & $115.42 \pm 0.15$ & $575.67 \pm 32.90$ & $1660.00 \pm$ & $61.00^{\mathrm{b}}$ & $32.88 \pm 2.35$ & $51.64 \pm 2.33^{\mathrm{c}}$ & $42.26 \pm 1.72^{\mathrm{b}}$ \\
\hline \multicolumn{2}{|l|}{$9 \%$} & $115.25 \pm 0.69$ & $561.42 \pm 17.62$ & $1716.00 \pm$ & $30.09^{\mathrm{b}}$ & $31.87 \pm 1.27$ & $54.98 \pm 1.02^{\mathrm{bc}}$ & $43.43 \pm 0.87^{b}$ \\
\hline \multirow{2}{*}{\multicolumn{2}{|c|}{$12 \%$}} & $114.58 \pm 0.45$ & $553.75 \pm 6.71$ & $1411.00 \pm$ & $17.58^{\mathrm{c}}$ & $31.37 \pm 0.46$ & $40.82 \pm 0.67^{\mathrm{d}}$ & $36.09 \pm 0.47^{\mathrm{c}}$ \\
\hline & & NS & NS & $* *$ & & NS & $* *$ & $* *$ \\
\hline \multicolumn{9}{|c|}{ Yeast effect (g/kg) } \\
\hline \multicolumn{2}{|l|}{0.0} & $114.50 \pm 0.38$ & $560.60 \pm 11.83$ & $1686.33 \pm$ & 46.11 & $31.86 \pm 0.84$ & $53.61 \pm 2.19$ & $42.74 \pm 1.13$ \\
\hline \multirow{2}{*}{\multicolumn{2}{|c|}{0.5}} & $114.83 \pm 0.28$ & $548.23 \pm 16.47$ & $1670.93 \pm$ & 48.94 & $30.96 \pm 1.18$ & $53.46 \pm 2.07$ & $42.21 \pm 1.27$ \\
\hline & & NS & NS & NS & & NS & NS & NS \\
\hline \multicolumn{9}{|c|}{ Interaction effect (BDG×yeast) } \\
\hline \multirow{2}{*}{ 0\% BDG } & $\mathbf{0 . 0}$ & $112.67 \pm 0.44$ & $581.00 \pm 40.63$ & $1876.00 \pm$ & 32.02 & $33.45 \pm 2.89$ & $61.67 \pm 1.36$ & $47.56 \pm 1.15$ \\
\hline & 0.5 & $114.17 \pm 0.33$ & $580.17 \pm 7.65$ & $1893.33 \pm$ & 76.35 & $33.29 \pm 0.54$ & $62.53 \pm 3.28$ & $47.91 \pm 1.91$ \\
\hline \multirow{2}{*}{$3 \%$ BDG } & 0.0 & $114.17 \pm 0.83$ & $525.67 \pm 22.24$ & $1749.00 \pm$ & 71.16 & $29.39 \pm 1.63$ & $58.25 \pm 2.34$ & $43.82 \pm 1.98$ \\
\hline & 0.5 & $115.17 \pm 0.33$ & $475.67 \pm 22.06$ & $1694.00 \pm$ & 58.80 & $25.75 \pm 1.55$ & $58.02 \pm 1.90$ & $41.88 \pm 1.63$ \\
\hline \multirow{2}{*}{$6 \%$ BDG } & $\mathbf{0 . 0}$ & $115.33 \pm 0.17$ & $572.50 \pm 36.98$ & $1651.33 \pm$ & 57.44 & $32.65 \pm 2.64$ & $51.37 \pm 4.34$ & $42.01 \pm 1.01$ \\
\hline & 0.5 & $115.50 \pm 0.29$ & $578.83 \pm 63.51$ & $1668.67 \pm$ & 123.41 & $33.10 \pm 4.54$ & $51.90 \pm 2.86$ & $42.50 \pm 3.70$ \\
\hline \multirow{2}{*}{$9 \%$ BDG } & 0.0 & $115.50 \pm 0.76$ & $562.17 \pm 19.14$ & $1746.67 \pm$ & 50.92 & $31.90 \pm 1.32$ & $56.41 \pm 1.58$ & $44.16 \pm 1.41$ \\
\hline & 0.5 & $115.00 \pm 1.32$ & $560.67 \pm 34.44$ & $1685.33 \pm$ & 31.55 & $31.83 \pm 2.52$ & $53.56 \pm 0.86$ & $42.69 \pm 1.14$ \\
\hline \multirow{3}{*}{$12 \%$ BDG } & 0.0 & $114.83 \pm 0.93$ & $561.67 \pm 11.23$ & $1408.67 \pm$ & 38.67 & $31.92 \pm 0.76$ & $40.33 \pm 1.31$ & $36.12 \pm 1.03$ \\
\hline & 0.5 & $114.33 \pm 0.33$ & $545.83 \pm 6.02$ & $1413.33 \pm$ & 6.67 & $30.82 \pm 0.41$ & $41.31 \pm 0.57$ & $36.06 \pm 0.13$ \\
\hline & & NS & NS & NS & & NS & NS & NS \\
\hline
\end{tabular}

Means in the same column within each classification bearing different letters are significantly different $(\mathrm{P}<0.05)$ $* *=$ Significant at $(\mathrm{P}<0.01)$ and NS $=$ Not significant.

presented in Table 3. It is worthy to note that, LBW and BWG through all the experimental periods were not significantly affected due to yeast supplementation at any level on broiler chicks diet compared to the unsupplemented ones. These results agree with Ayanwale et al. (2006), Morales-Lopeze et al. (2009), AlMansour et al. (2011) and Adebiyi et al. (2012), who reported that, yeast products had no effect on the growth rate in broiler chicks and turkey poults. On the other hand, several researchers (Santin et al., 2001; Nilson et al., 2004; Zhang et al., 2005; Hosseini, 2011; Fathi et al., 2012) noticed that BW during earlier age through the first four weeks did not significantly improved by the dietary inclusion of yeast supplementation, suggesting that, yeast culture did not play an active role in BW during initial stage of growth period. Similarly, Fasina and Thanissery (2011) observed that, the BW of yeast supplemented group of chicks hatched from young breeder hens did not differ from chicks of unsupplemented group. It should be noted that, inclusion of yeast in broiler ration 
significantly improved body weight particularly in latter ages (4-6 weeks of age) compared with unsupplemented ones. Furthermore, Chae et al. (2006) and Zhang et al. (2011) concluded that supplementation of broiler chicken diets with yeast culture wall or purified fractions has resulted in improvements of body weight gain. However many researchers attributed the different response of birds to the supplementation due to the nature of the experiment condition. It has been reported that in order for the yeast products to be effective, the birds need to kept under stress in some way (Cruickshank, 2002).

\section{Interaction effect (dietary BDG $\times$ yeast supplementation)}

The interaction effect due to dietary BDG and yeast supplementation on the LBW and BWG during the experimental periods are shown in Table 3. In view of the results, it seems that, the interaction effects between dietary BDG and yeast supplementation were not significant among the treatment groups on LBW and BWG during the different experimental studied periods (starter, finisher and the whole experimental periods). It is worthy to note that through 1-6 weeks of age chicks fed on diet contained 0.0 BDG with or without yeast supplementation recorded insignificantly higher LBW and BWG values when compared with other treatments. On the other hand the lowest values of LBW and BWG was showed for chicks fed on diets contained $12 \%$ BDG with or without yeast supplementation. However, Oydeji et al. (2008) concluded that, yeast fed at either 250 or $300 \mathrm{mg} / \mathrm{kg}$ diet to supplement $26 \%$ inclusion of BDG in broiler starter diet could enhance significantly $(\mathrm{P}<0.05)$ body weight gain.

\section{Feed intake and feed conversion}

Concerning feed intake (FI), the present findings in Table 4 demonstrate that, there were insignificant differences among the different experimental groups of BDG and control groups. It could be noticed that, average feed intake values were insignificantly decreased with increasing dietary BDG through the whole experimental period (1-6 weeks of age, while the average FI values were similar among BDG treatments and control during the periods from 1-3 and $<3-6$ weeks of age).
The present results agree with the previous results of Diriba (1991), Wondifraw and Berhan, (2014), who reported insignificant differences $(\mathrm{p}<0.05)$ in the mean dry matter intake between starter diet chicks containing 25\% BDG and their counterpart fed the control diet which might be due to the fact that all diets contain similar levels of nutritive value mainly energy, protein and crude fiber.

This is an advantage for procedurs, as BDG is regarded as a waste material that can bought cheaply and reduce the production cost without affecting the feed consumption (Wondifraw and Berhan 2014).

Results illustrated in Table 4 show that, feed conversion ratio (FCR) was significantly $(\mathrm{P}<0.01)$ due to the addition of BDG in brioler chicks diet, through the periods from $<3-6$ weeks of age and the whole experimental period. It could be noticed that, chicks fed on diet contained 9\% BDG and control (0.0 BDG) had achieved the best FCR values. While the poorest FCR value was recorded for birds fed on diet contained 12\% BDG when compared with the other treatment groups $(3,6$ and $9 \%$ BDG). This may be due to the reduction in BWG as a result of BDG inclusion. The result agreed with the literature that, BDG contains high concentration of non starch polysaccharides and some tannis which have been shown to interfere efficiency of feed utilization in monogastric, inhibits the absorption of essential nutrients, inhibits digestive enzymes hence, decrease feed utilization (Lacassagne et al., 1998). However Hussaini et al. (2010) suggested that birds fed diet containing $7.5 \%$ BSG have a more FCR than control groups (0.0 BSG). Wondifraw and Berhan (2014) found, a significantly $(\mathrm{P}<0.05)$ lower dry matter conversion ratio in white leghorn chicks fed 24 and 30\% BDGY than the rest of dietary treatments $(6,12$ and $18 \%$ BDG). Also Alabi et al. (2014) showed that, an increase in the dietary level of BDG, significantly $(p<0.05)$ decreased feed conversion value.

\section{Effect of dried yeast supplementation}

The results presented in Table 4 indicate that each of feed intake and feed conversion ratio were not significantly affected by the presence of dried yeast in the diet during the all experimental periods studied. 
Table 4. Feed intake and feed conversion $(\bar{X} \pm \mathrm{SE})$ for broiler chickens as affected by brewers dried levels, yeast supplementation and their interactions

\begin{tabular}{|c|c|c|c|c|c|c|c|}
\hline \multirow[t]{2}{*}{ Item } & & \multicolumn{3}{|c|}{ Feed intake (g/day) } & \multicolumn{3}{|c|}{ Feed conversion (g feed/g gain) } \\
\hline & & $1-3$ wks & 3-6 wks & $1-6$ wks & $1-3$ wks & 3-6 wks & $1-6$ wks \\
\hline \multicolumn{8}{|c|}{$\overline{\text { Brewers dried (BDG) effect }}$} \\
\hline \multicolumn{2}{|c|}{$0 \%$} & $66.17 \pm 0.87$ & $143.33 \pm 9.72$ & $117.67 \pm 6.50$ & $2.02 \pm 0.07$ & $2.32 \pm 0.20^{\mathrm{a}}$ & $2.15 \pm 0.10^{\mathrm{a}}$ \\
\hline \multicolumn{2}{|l|}{$3 \%$} & $60.33 \pm 1.61$ & $143.75 \pm 3.75$ & $115.83 \pm 2.66$ & $2.20 \pm 0.12$ & $2.48 \pm 0.06^{\mathrm{ab}}$ & $2.33 \pm 0.05^{\mathrm{ab}}$ \\
\hline \multicolumn{2}{|l|}{$6 \%$} & $64.33 \pm 0.84$ & $142.92 \pm 5.21$ & $116.67 \pm 3.54$ & $2.02 \pm 0.15$ & $2.78 \pm 0.14^{\mathrm{b}}$ & $2.40 \pm 0.07^{\mathrm{b}}$ \\
\hline \multicolumn{2}{|l|}{$9 \%$} & $59.17 \pm 2.93$ & $134.17 \pm 6.45$ & $109.33 \pm 4.36$ & $1.85 \pm 0.07$ & $2.45 \pm 0.13^{\mathrm{ab}}$ & $2.13 \pm 0.08^{\mathrm{a}}$ \\
\hline \multirow{2}{*}{\multicolumn{2}{|c|}{$12 \%$}} & $62.67 \pm 0.95$ & $134.67 \pm 2.19$ & $110.67 \pm 1.58$ & $2.02 \pm 0.05$ & $3.30 \pm 0.04^{\mathrm{c}}$ & $2.67 \pm 0.04^{\mathrm{c}}$ \\
\hline & & NS & NS & NS & NS & $* *$ & $* *$ \\
\hline \multicolumn{8}{|c|}{ Yeast effect $(\mathrm{g} / \mathrm{kg})$} \\
\hline \multicolumn{2}{|l|}{0.0} & $62.07 \pm 0.97$ & $143.10 \pm 3.97$ & $116.07 \pm 2.81$ & $1.97 \pm 0.05$ & $2.73 \pm 0.12$ & $2.35 \pm 0.06$ \\
\hline \multirow{2}{*}{\multicolumn{2}{|c|}{0.5}} & $63.00 \pm 1.37$ & $136.43 \pm 3.38$ & $112.00 \pm 2.24$ & $2.07 \pm 0.08$ & $2.61 \pm 0.12$ & $2.33 \pm 0.07$ \\
\hline & & NS & NS & NS & NS & NS & NS \\
\hline \multicolumn{8}{|c|}{ Interaction effect (BDG $\times$ yeast) } \\
\hline \multirow{2}{*}{ 0\% BDG } & $\mathbf{0 . 0}$ & $65.00 \pm 1.00$ & $156.50 \pm 15.67$ & $126.00 \pm 10.69$ & $2.00 \pm 0.15$ & $2.53 \pm 0.34$ & $2.27 \pm 0.12$ \\
\hline & 0.5 & $67.33 \pm 1.20$ & $130.17 \pm 7.34$ & $109.33 \pm 5.24$ & $2.03 \pm 0.03$ & $2.10 \pm 0.20$ & $2.03 \pm 0.13$ \\
\hline \multirow{2}{*}{ 3\% BDG } & 0.0 & $59.67 \pm 1.86$ & $147.83 \pm 6.01$ & $118.33 \pm 4.37$ & $2.00 \pm 0.06$ & $2.53 \pm 0.12$ & $2.30 \pm 0.06$ \\
\hline & 0.5 & $61.00 \pm 3.00$ & $139.67 \pm 4.21$ & $113.33 \pm 3.18$ & $2.40 \pm 0.15$ & $2.43 \pm 0.03$ & $2.37 \pm 0.09$ \\
\hline \multirow{2}{*}{$6 \%$ BDG } & 0.0 & $63.67 \pm 0.88$ & $142.50 \pm 6.50$ & $116.00 \pm 4.62$ & $2.00 \pm 0.15$ & $2.83 \pm 0.30$ & $2.40 \pm 0.10$ \\
\hline & 0.5 & $65.00 \pm 1.53$ & $143.33 \pm 9.67$ & $117.33 \pm 6.39$ & $2.03 \pm 0.29$ & $2.73 \pm 0.03$ & $2.40 \pm 0.12$ \\
\hline \multirow{2}{*}{ 9\% BDG } & 0.0 & $61.00 \pm 4.16$ & $134.50 \pm 6.25$ & $110.33 \pm 5.49$ & $1.90 \pm 0.15$ & $2.40 \pm 0.10$ & $2.13 \pm 0.12$ \\
\hline & 0.5 & $57.33 \pm 4.70$ & $133.83 \pm 12.98$ & $108.33 \pm 8.01$ & $1.80 \pm 0.00$ & $2.50 \pm 0.26$ & $2.13 \pm 0.12$ \\
\hline \multirow{3}{*}{$12 \%$ BDG } & 0.0 & $61.00 \pm 1.00$ & $134.17 \pm 3.09$ & $109.67 \pm 1.76$ & $1.93 \pm 0.07$ & $3.33 \pm 0.03$ & $2.63 \pm 0.07$ \\
\hline & 0.5 & $64.33 \pm 0.88$ & $135.17 \pm 3.77$ & $111.67 \pm 2.91$ & $2.10 \pm 0.06$ & $3.27 \pm 0.09$ & $2.70 \pm 0.06$ \\
\hline & & NS & NS & NS & NS & NS & NS \\
\hline
\end{tabular}

Means in the same column within each classification bearing different letters are significantly different $(\mathrm{P}<0.05)$ $* *$ Significant $(\mathrm{P}<0.01)$ and NS $=$ Not significant.

The present results are in agreement with those reported by Gao et al. (2008) and Markovic et al. (2009) who indicated that, dried yeast preparations failed to obtain a significant effect on feed intake and feed conversion ratio of broiler chicks.

\section{Interaction effect (dietary BDG $\times$ yeast supplementation)}

It could be noticed from Table 4 that, insignificant interaction due to dietary BDG and yeast supplementation on feed intake and feed conversion ratio was noted during the different experimental periods. It is worthy to noting that, for the entire experiment (1-6 weeks of age) the data revealed that, broiler chicks fed diets without BDG inclusion, unsupplemented yeast consumed the highest value (126.09 g). On the contrary, chicks fed diets contained 12\% BDG without yeast supplementation and 9\% BDG with yeast supplementation consumed the lowest values (109.67 and $108.33 \mathrm{~g}$, respectively).

Concerning FCR, chicks fed diet without BDG, supplemented with yeast supplementation had the best feed conversion ratio (2.03) while chicks feed diet contained 12\% BDG supplemented with yeast had the poorest feed conversion ratio (2.7). 
Contradicting results were obtained by Oyedeji et al. (2008) who found that, during starter phase, Ross 355 broiler chicks feed diet contained $26 \%$ BDG with 250 or $300 \mathrm{mg}$ yeast $/ \mathrm{kg}$ diet recorded the best feed conversion ratio.

Alabi et al. (2014) found that, increasing in dietary level of BDG, supplemented with enzyme improved feed/gain ratio and they stated, that there were significant interaction $(\mathrm{P}<0.05)$ between levels of BDG and enzyme supplementation on feed intake and feed/gain ratio.

\section{Some Carcass Traits}

\section{Effect of BDG level}

In view of the results in Table 5, it seems that, the dietary BDG level had no significant effect on carcass and dressing percentage. However, there was significant $(\mathrm{p}<0.01)$ effect of dietary BDG level on the giblet percentage, in which it was lower in chicks fed on diet contained 6 and 9\% BDG when compared with control and other treatment groups (3 and 12\% BDG). These results are in good line with Deltro and Caromona (1981) who, evaluated BDG at levels of $0,10,20,30$ and $40 \%$ in broiler chicks diet and reported insignificant differences in average dressing percentage up to $20 \%$ inclusion level. They also observed that, when 20\% inclusion level or more BDG was used, there were significantly $\mathrm{P}<0.05$ reduced abdominal fat pad and meat tissue with no effects on bone tissue. Chumpawadee et al. (2008) also reported that inclusion of BDG in broiler diets did not have any significant effects on carcass cut Kokol et al. (2012) found that, most of the carcass traits evaluated were not significantly $(\mathrm{p}<0.05)$ affected by dietary BDG expect thigh and gizzarad percentages were significantly $(\mathrm{P}<0.05)$ different among treatment groups.

\section{Effect of dried yeast supplementation:}

Results in Table 5 did not show any significant effect on carcass traits studied due to the supplementation of dried yeast in broiler chicks diet. Likewise, Karaoglu and Dardag (2005) and Chumpawadee et al. (2008), found that, yeast (Sacharomyces cerevisiae) supplementation in broiler diet did not have any effect on hot or cold carcass percentage. On the other hand, Abou El-Naga (2012) found that, dry yeast supplementation significantly $(\mathrm{P}<0.05)$ improved the carcass characteristics of broiler chicks.

Fathi et al. (2012) revealed improvement in carcass yield of broiler fed yeast culture supplementation diet. Hosseini (2011) found a significant $(\mathrm{P}, 0.05)$ percentage of carcass, liver, heart and gizzard in broiler fed ration containing Saccharomyces cerevisiae compared to untreated siblings. Miazzo et al. (2005) also reported that the broiler fed yeast $(0.3 \%)$ had a higher leg muscle than the other group fed a basal diet without yeast inclusion. Onifade (1997) stated that, broiler chicks fed diet yeast had significantly $(\mathrm{P}<0.05)$ greater weight of liver spleen, and gizzard compard to the control siblings. In broiler fed yeast extract (nucleotide source), Rutz et al. (2006) observed a numerical improvement in carcass yield, as well as in drum, thigh, wing and breast yields as compared to birds that did not receive yeast extract.

\section{Interaction effect (dietary BDG $\times$ yeast supplementation}

From the results in Table 5, it's worthy to note that, there were not any significant effect due to the interaction between dietary BDG $\mathrm{x}$ yeast supplementation on the average of dressing and carcass percentages. On the other hand, there were significant $(\mathrm{P}<0.05)$ differences among the treatment groups on giblets (\%) content due to the interaction between dietary BDG yeast supplementation. The results showed that, the highest giblets (\%) value was obtained by chicks fed on diets contained (12\%) BDG with yeast supplementation, while, the lowest one (\%) was obtained by the chicks fed on the diet contained $9 \%$ BDG with yeast supplementation.

Okorie et al. (2011) found that broiler chicks fed diet containing 20 or $30 \%$ BDG with syenthetic enzyme (Zympex) supplementation $(1 \mathrm{~g} / \mathrm{kg})$ diet during finisher period were recorded $(p<0.05)$ the highest values of gizzard (\%) when compared with other treatment groups. Also carcass characteristics showed that the eviscerated weight, the breast muscle, thigh/drumstick and the back were significantly $(p<0.05)$ high in broiler chicks fed diets containing 10 or $20 \%$ BDG supplemented with enzyme. 
Table 5. Some carcass traits ( $\bar{X} \pm \mathrm{SE})$ for broiler chickens as affected by brewers dried levels, yeast supplementation, economical efficiency and their interactions

\begin{tabular}{|c|c|c|c|c|c|c|}
\hline \multicolumn{2}{|l|}{ Item } & $\begin{array}{c}\text { Pre-slaughter } \\
\text { weight (g) }\end{array}$ & $\begin{array}{c}\text { Dressing } \\
(\%) \\
\end{array}$ & $\begin{array}{c}\text { Carcass } \\
(\%) \\
\end{array}$ & $\begin{array}{c}\text { Giblets } \\
(\%) \\
\end{array}$ & $\begin{array}{l}\text { Economi } \\
\text { efficienc }\end{array}$ \\
\hline \multicolumn{7}{|c|}{ Brewers dried (BDG) effect } \\
\hline \multicolumn{2}{|l|}{$0 \%$} & $1960.00 \pm 56.62^{\mathrm{a}}$ & $74.19 \pm 0.81$ & $68.58 \pm 0.87$ & $5.62 \pm 0.15^{\mathrm{a}}$ & 0.88 \\
\hline \multicolumn{2}{|l|}{$3 \%$} & $1700.00 \pm 52.68^{b}$ & $70.27 \pm 3.18$ & $64.51 \pm 3.18$ & $5.76 \pm 0.11^{\mathrm{a}}$ & 0.76 \\
\hline \multicolumn{2}{|l|}{$6 \%$} & $1752.50 \pm 86.54^{\mathrm{b}}$ & $75.11 \pm 0.55$ & $69.85 \pm 0.65$ & $5.26 \pm 0.12^{\mathrm{b}}$ & 0.76 \\
\hline \multicolumn{2}{|l|}{$9 \%$} & $1832.50 \pm 35.04^{\mathrm{ab}}$ & $73.56 \pm 0.23$ & $68.37 \pm 0.36$ & $5.19 \pm 0.17^{\mathrm{b}}$ & 0.98 \\
\hline \multirow{2}{*}{\multicolumn{2}{|c|}{$12 \%$}} & $1548.75 \pm 27.26^{\mathrm{c}}$ & $74.19 \pm 0.81$ & $68.12 \pm 0.32$ & $5.80 \pm 0.17^{\mathrm{a}}$ & 0.64 \\
\hline & & $* *$ & NS & NS & $* *$ & \\
\hline \multicolumn{7}{|c|}{ Yeast effect (g/kg) } \\
\hline \multicolumn{2}{|l|}{0.0} & $1746.00 \pm 49.37$ & $74.49 \pm 0.34$ & $68.98 \pm 0.36$ & $5.51 \pm 0.09$ & 0.84 \\
\hline \multirow{2}{*}{\multicolumn{2}{|c|}{0.5}} & $1771.50 \pm 49.17$ & $72.33 \pm 1.31$ & $66.79 \pm 1.34$ & $5.54 \pm 0.13$ & 0.76 \\
\hline & & NS & NS & NS & NS & \\
\hline \multicolumn{7}{|c|}{ Interaction effect (BDG $\times$ yeast) } \\
\hline \multirow{2}{*}{ 0\% BDG } & $\mathbf{0 . 0}$ & $1967.50 \pm 30.31^{\mathrm{a}}$ & $75.80 \pm 0.31$ & $70.40 \pm 0.06$ & $5.40 \pm 0.25^{\mathrm{bc}}$ & 0.93 \\
\hline & 0.5 & $1952.50 \pm 122.69^{\mathrm{a}}$ & $72.58 \pm 0.78$ & $66.75 \pm 0.69$ & $5.83 \pm 0.08^{\mathrm{ab}}$ & 0.82 \\
\hline \multirow{2}{*}{ 3\% BDG } & 0.0 & $1700.00 \pm 112.58^{\mathrm{bc}}$ & $75.37 \pm 0.93$ & $69.55 \pm 1.17$ & $5.82 \pm 0.24^{\mathrm{ab}}$ & 0.84 \\
\hline & 0.5 & $1700.00 \pm 34.64^{\mathrm{bc}}$ & $65.16 \pm 4.86$ & $59.46 \pm 4.87$ & $5.69 \pm 0.01^{\mathrm{b}}$ & 0.68 \\
\hline \multirow{2}{*}{$6 \%$ BDG } & $\mathbf{0 . 0}$ & $1590.00 \pm 28.87^{\mathrm{c}}$ & $74.57 \pm 0.32$ & $69.20 \pm 0.53$ & $5.37 \pm 0.21^{\mathrm{bc}}$ & 0.73 \\
\hline & 0.5 & $1915.00 \pm 101.04^{\mathrm{ab}}$ & $75.64 \pm 1.05$ & $70.50 \pm 1.18$ & $5.14 \pm 0.13^{\mathrm{cd}}$ & 0.79 \\
\hline \multirow{2}{*}{ 9\% BDG } & $\mathbf{0 . 0}$ & $1910.00 \pm 0.00^{\mathrm{ab}}$ & $73.45 \pm 0.48$ & $67.93 \pm 0.68$ & $5.52 \pm 0.20^{\mathrm{bc}}$ & 0.98 \\
\hline & 0.5 & $1755.00 \pm 11.55^{\mathrm{abc}}$ & $73.66 \pm 0.10$ & $68.80 \pm 0.04$ & $4.86 \pm 0.06^{\mathrm{d}}$ & 0.99 \\
\hline \multirow{3}{*}{$12 \%$ BDG } & 0.0 & $1562.50 \pm 53.40^{\mathrm{c}}$ & $73.23 \pm 0.21$ & $67.82 \pm 0.27$ & $5.41 \pm 0.05^{\mathrm{bc}}$ & 0.74 \\
\hline & 0.5 & $1535.00 \pm 25.98^{c}$ & $74.60 \pm 0.57$ & $68.42 \pm 0.59$ & $6.18 \pm 0.02^{\mathrm{a}}$ & 0.54 \\
\hline & & $*$ & NS & NS & $* *$ & \\
\hline
\end{tabular}

Means in the same column within each classification bearing different letters are significantly different $(\mathrm{P}<0.05)$ $* *=$ Significant $(\mathrm{P}<0.01)$ and $\mathrm{NS}=$ Not significant.

\section{Economical Efficiency}

\section{Effect of BDG level}

The presented data (Table5) clearly demonstrate that, feed cost $/ \mathrm{kg}$ gain increased and economical efficiency decreased in chicks fed diets containing 3,6 and $12 \%$ BDG compared with control. On the other hand feed cost $/ \mathrm{kg}$ gain decreased and EE increased in chicks fed diet containing 9\% BDG. This may be due to the improvement of FCR in groups fed $9 \%$ BDG when compared with control and other treatment group (3, 6 and $12 \% \mathrm{BDG})$.

It is worthy noting that, the lowest values of feed cost $/ \mathrm{kg}$ gain and the best EE were observed for broiler chicks fed on diet contained 9\% BDG. However chicks fed on a $12 \%$ BDG diet showed the highest value of feed cost $/ \mathrm{kg}$ gain and the lowest economical efficiency during the 
whole experimental period. Wondifraw and Berhan (2014) indicated that, the inclusion of BDGY at $18 \%$ inclusion level chicks ration reduces production cost, economical feasible and brought high economical efficiency without affecting growth performance (LBW, BWG, FI and FCR ) of chicks as compared to the control diet. Thus, in view of the shortage and the high costs of protein feed stuffs exploitation of industrial by-products may make a substantial contribution towards better and more economical feeding of poultry.

\section{Effect of yeast supplementation}

The results presented in Table 5 show the effect of yeast supplementation irrespective of dietary level on feed cost $/ \mathrm{kg}$ gain and EE of broiler chicks during 1-6 weeks of age. The value of feed cost $/ \mathrm{kg}$ gain increased and $\mathrm{EE}$ decreased due to yeast supplementation in broiler chicks, diet (Table 5). Which may be due to poorest FCR. Contradicting results were obtained by Abou El-Naga (2012) who show that, the highest $\mathrm{EE}$ and relative $\mathrm{EE}$ values were obtained with the diet of $0.5 \%$ dried yeast which could be due to improving FCR or reducing the required to produce $\mathrm{BWG}$.

\section{Interaction effect (dietary BDG $\mathrm{x}$ yeast supplementation)}

From the present data (Table5) it seems that, the best feed cost $/ \mathrm{kg}$ gain and $\mathrm{EE}$ attributable to the group fed on a diet containing 9\% BDG with or without yeast supplementation as compared with the other dietary treatments during 1-6 weeks of age. On the other hand, the highest feed cost $/ \mathrm{kg}$ gain and the lowest EE values were obtained from chicks fed diet containing $12 \%$ BDG level with yeast supplementation (Table 5).

\section{Conclusion}

The results of this study indicated that, taking body weight gain, the feed conversion and economical efficiency the dietary level of $9 \%$ BDG with or without supplementation yeast culture may be the best percentage till 6 weeks of age. Yeast culture did not affect on the performance and carcass traits.

\section{REFERENCES}

Abou El-Naga (2012). Effect of dietary yeast supplementation on broiler performance. Egypt. Poult. Sci., 32 (I): 95-106.

Adebiyi, O.A., B.A. Makanjola, T.O. Bankole and A.S. Adeyori (2012). Yeast culture (Saccharomyces cerevisae) Supplementation: Effect on the performance and gut morphology of broiler birds. Global J. Sci. Frontier Res. Biol. Sci., $12: 6$.

Adejumo, D.O., A.A. Onifade, T.O. Olutende and G.M. Babatunde (2005). The effects of concentration, age and duration of feeding supplemental yeast (Levuel SB) in a high fibre diet on the performance of broiler chickens. J. Sus. Trop. Agric. Res., 13 : 5865 .

Aghabeigi, R., S. Moghaddaszadeh-Ahrabi and M. Afrouziyeh (2013). Effect of brewers spent grain on performance and protein digestibility in broiler chickens.

Alabi, O.O., J.O. Atteh, I.O. Adejumo and O.O. Ogundele (2014). Effects of dietary levels of brewers' dried grain supplemented with commercial enzymes on performance, nutrient retention and gastro-intestinal tract characteristics of arbor acres broilers. Int. J. Agric. Innovations and Res., 2 (5): 319-473.

Al-Mansour, S., A. Al-Khalf, I. Al-Homidan and M.M. Faathi (2011). Feed efficiency and blood hematology of chicks given a diet supplemented with yeast culuture, Int. J. Poult. Sci., 10:603-607.

Aregherore, E.M. and S.A. Abdulrazak (2005). Estimation of organic matter digestibility and metaboliszable energy content of agroindustrial waste using in vitrogas production. Nig. J. Anim. Prod., 32 (1): 10-79.

Ayanwale, B.A., M. Kpe and V.A. Ayanwale (2006). The effect of supplementing Saccharomyces cerevisiae in the diets on egg laying and egg quality characteristics of pullets. Int. Poult. Sci., 5: 759-763.

Chae, B.J., J.D. Lohakare, W.K. Moon, S.L. Lee, Y.H. Park and T.W. Hahn (2006). Effects of supplementation B-glucan on the 
growth performance and immunity in beoilers. Res. Vet. Sci., 80: 291-298.

Chumpawadee, S., O. Chinrssri, T. Somchan, S. Ngamluan and S. Soychuta (2008). Effect of dietry inclusion of Cassava Yeast as probiotic source on growth performance, small intestine (ileum) morphology and carcass characteristic in broilers. Int. J. Poult. Sci., $7: 246-250$.

Cruickshank, G. (2002) Boosting performance, health and product quality. Poult. World 21, October, 16.

Denstadli, V., B. Westereng, H.G. Biniyam, S. Ballance, S.H. Knutsen and B. Svihus (2010). Effects of structure and xylanase treatment of brewers' spent grain on performance and nutrient availability in broiler chickens. Br. Poult. Sci., 51 : 419-426.

Deltro, L.J. and J.F. Caromona (1981). Evaluation of brewer's dried grains in the diets of broiler chickens. Anim. Feed Sci. Technol., 6 (2): 179-188

Diriba, D. (1991). The study of the nutritive and supplementary value of different levels of brewers dried grains in starter chicks rations. An M.Sc. Thesis Pres. to the School of Gradnate Studies of Alemaya. Univ. Ethiopia., 62.

Duncan, D.B. (1955). Multiple Range and Multiple F Tests. Biometrics, 11: 1-42.

Fasina, Y.O. and R.R. Thanissery (2011). Comparative efficiency of a yeast product and bacitracin methylene disalicylate in enhancing early growth and intestinal maturation in broiler chicks from breeder hens of different ages. Poult. Sci., 90 : 10671073.

Fathi, M.M., S. Al-Mansour, A. Al-Homidan, A. Al-Khalf and M. Al-Damegh (2012). Effect of yeast culture supplementation on carcass yield and humoral immune response of broiler chicks. Vet. World, 5 (11): 651-657.

Gao, J., H.J. Zhang, S. H. Yu , S.G. Wu,I. Yoon, J. Qurgley, Y. P. Gao and G. H. Qi (2008). Effects of yeast culture in broiler diets on performance and immune-modulatory functions. Poul. Sci., 87:1377-1384.
Heady, E.O. and H.R. Jensen (1954). Farm Management Economics. Prentice- Hall Inc. Englewood Cliffs, N. J., USA.

Hosseini, S. (2011). The effect of utilization of different levels of Saccharomsec cerevisiae on broiler chickens performance. Global Vet. 6:223-236.

Hussaini, S.J., H.N. Moghaddam and H. Kenshahirma (2010). The influence of different levels of brewers spent grain and enzyme on performance and digesta viscosity of broiler chicks. J. Anim. and Vet., $9: 2608$ 2612.

Karaoglu, M. and H. Dardag (2005). The influence of dietary probiotic (Saccharomyces cerevisiae) supplementation and different slaughter age on the performance, slaughter and carcass properties of broiler. Int. J. Poult. Sci., 4 (5): 309-316.

Kokol, C., U. Zaklag, M. Antyev, F.T. Akade and M.J. Baba (2012). Response of broiler finisher fed graded levels of brewers dried grain on carcass and internal organ characteristics. J. Agric. and Vet. Sci., 4.

Lacassagne, L., M. Francesch, B. Caire and J.P Mekion (1998). Utilization of tannin containing and tannin free faba beans (Vicia $f a b a$ ) by young chicks. Effects of pelleting feed on energy, protein and starch digestibility. Anim. Feed Sci. and Technol., 70 : 57 - 68.

Longe, P.G. and J.A. Adetola (1983). Metabolizable energy value of some agricultural wastes and industrial by-product for layers and effect of these ingredients on gut dimension. J. Anim. Prod. and Res.

Longstaff, M. and M.C. Nab (1989). Digestion of fibre polysaccharides of pea (Psium sativum) hulls, carrot and cabbage by adult cockerels. Br. J. Nut., 62: 563-577.

Markovic, R., D. Sefera, M. Krstic and Petrujikic (2009). Effect of different growth promoters on broiler performance and gut morphology. Arch. Med. Vet., 41 : 163-169.

Miazzo, R.D., M.F. Peralata and M. Picco (2005) Performance productively calidad de la canal en broilers que recibieron lavadara de cerveza (S. cerevisiae). Revista Electronica de Vet., 12:1-9. 
Morales-Lopeze, R., E. Auclair, F. Garcia, E. Esteve-Garcia and J. Brufau (2009.) Use of yeast cell walls; â-1,3/1,6-glucans; and mannoproteins in broiler chicken diets. Poult. Sci., 88: 601-607.

Nilson, A., J.MF. Peralla and R.D. Miazzo (2004). Use of brewers yeast (S. cerevisiae) to replace part of the vitamin-mineral premix in finisher broiler diets. XXII World Poultry Congrees, Istanbul, Turkey.

Noll, S., V. Stangeland, G. Speers and J. Brannon (2001). Minnesota nutrition conference and Minnesota corn growers association technicl symposium, Bloomington, MN.

NRC (1994). National Research Council. Nutrient requirements of poultry. $9 \mathrm{t}^{\mathrm{h}} \mathrm{Ed}$. Nat. Acad. Press, Washington. DC.

Okorie, K.C., O.Z.E. Gabriel, F.N. Ehirim, R.C. Okorie, J.N. Ikpe, C.T. Muoneme, C. OkoroUgo and C.S. Nwosu (2011). Effect of synthetic enzyme fortified brewers dried grain as feed source on broilers finisher; performance, hematology and biochemical profiles. Global Res. J. Sci.ISSN 2276-8300.

Onifade, A.A. (1997). Growth performance, carcass characteristics, organ measurements and hematology of broiler chickens fed a high fiber diet supplemented with antibiotics or dietary yeast. Dienahrung , 41,370-374.

Oydeji, J.O., H.I. Ajayi and T. Egere (2008). The effects of increasing levels of yeast culutre (Levucel SB) in a high fibre-diet on the performance and nutrient retention of broiler chicks. Asian J. Poult. Sci., 2 (1) : 5357.

Parsons, C.M., D.H. Baker and J.M. HarterDennis (1983). Distillers dried grains with solubles as a protein source for the chick. Poult. Sci., 62: 2445-2451.

Rutz, F., M.A. Anciuti, J.L. Rech, F.M. Goncalves, A.D. Delgado, E.R. Rosa, N. Zauk, C.L.G. Ribeiro, R.R. Silva and P.R.
Dallmann (2006). Desempenho caracteristicas de carcass de frangos de corte recebendo extrato de levedura na dieta. Ciencia Anim. Brasileira, 7 : 349-355.

Sabet, M.A., M. Mehdipour and B. Dastar (2009). The determining of digestible energy and digestibility coefficients of protein, calcium and phosphorus of malt (Germinated Barley) in broilers. Int. J. Poult. Sci., 8:788791.

Santin, E., A. Maiorka, M. Macari, M. Grecco, J.C. Sanchez, T.M. Okada and A.M. Myasaka (2001). Performance and intestinal mucosa development of broiler chickens fed diets containing Saccharomyces cerecvisiae cell wall. J. Appl. Poult. Res., 10 : 236-244.

Snedecor, G.W. and W.G. Cochran (1982). Statistical Methods. $6^{\text {th }}$ Ed., Iowa State University Press, Ames, USA, 593.

SPSS (1999). Statistical software package for the social sciences. SPSS, Int., USA.

Wondifraw, Z. and T. Berhan (2014). The effect of feeding different levels of brewer's dried grain yeast mixture on the performance of white leghorn chicks. Int. J. Livest. Prod., 5 (1): 10 - 14 .

Zhang, A.W., B.D. Lee, S.K. Lee, K.W. Lee, G.H. An, K.B. Song and C.H. Lee (2005). Effect of yeast (Saccharomyces cerevisiae) cell componants on growth performance, meat quality and ileal mucosa development of broiler chicks. Poul. Sci., 84:1015-1021.

Zhang, S., B. Liao, L. Li, L. Ma and X. Yan (2011). Effects of yeast cell walls performance and immune responses of cyclosporine A- treated, immune suppressed broiler chickens. Br. J. Nut. P 1 of 9, doi: 10.1017/S000711451100362. 
تأثير كلا من تفل البيرة الجاف والخميرة الجافة على معلات النمو وصفات الذبيحة باجاج التسمين

$$
\begin{aligned}
& \text { محمد أحمد نور- محمد محمد الهنداوى ـ عادل إبراهيم عطيه ـ علوى على عاشور } \\
& \text { قسم الدو اجن - كلية الزر اعة - جامعة الزقازيق ـ مصر }
\end{aligned}
$$

تم إجراء هذه التجربة لدراسة تأثير مستويات مختلفة من تفل البيرة الجافة ومستويين من الخمبرة الجافة

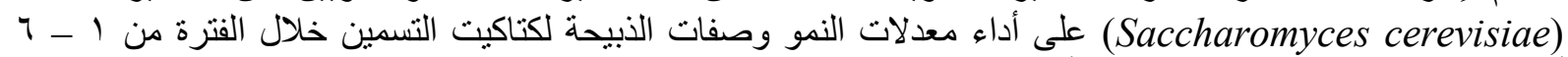

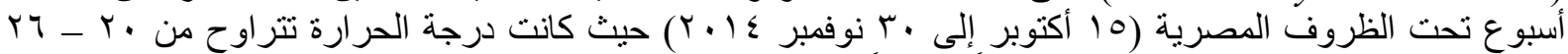

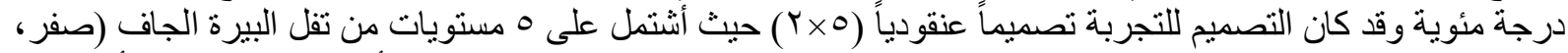

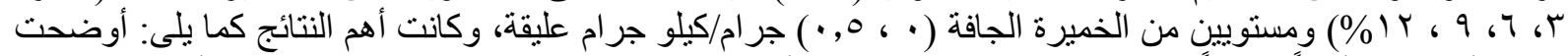

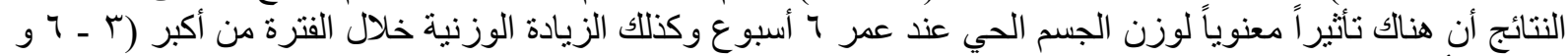

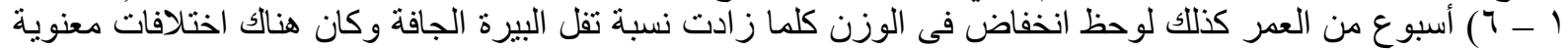

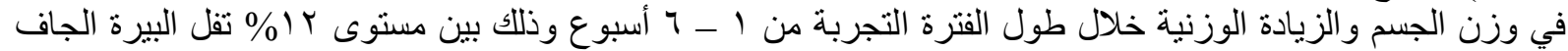

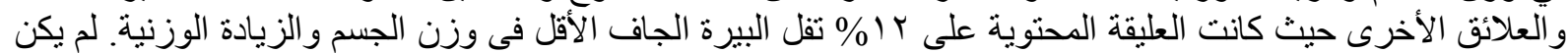

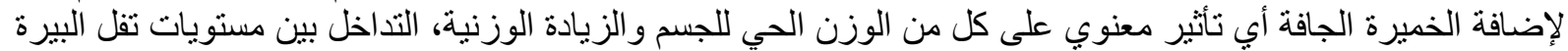

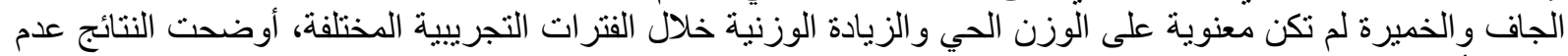

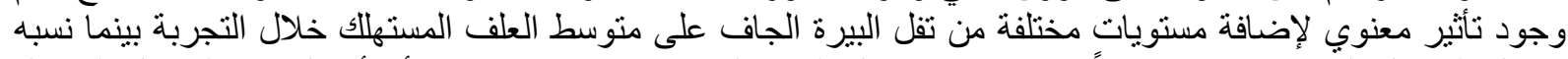

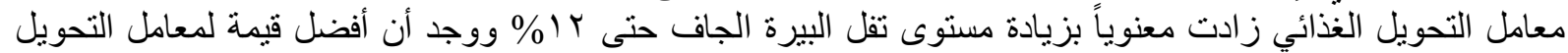

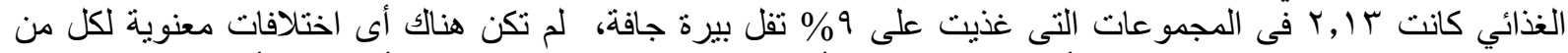

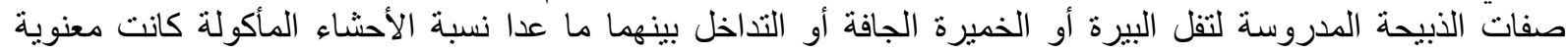
(P > 0.01)

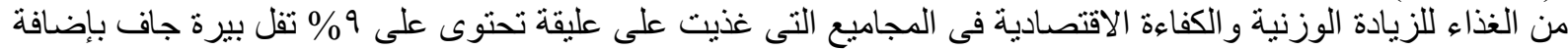

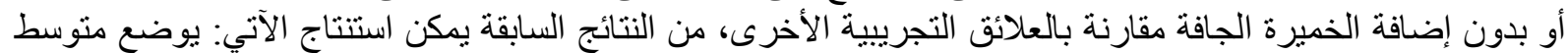

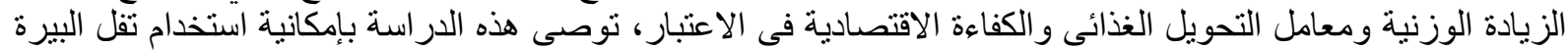
الجافة بمستوى 9\% بإضافة أو بدون إضافة الخميرة الجافة حيث يمكن أن تعطى أفضل الداء أداء إنتاجي حتى 7 أسابيع من

أستاذ تغذية الدو اجن - مركز بحوث الصحر اء. أستاذ تغذية الدواجن المتفرغ - كلية الزر اعة - جامعة الزقازيق. 